\title{
CHALLENGES FOR INCLUSIVE HIGHER EDUCATION
}

\author{
Tsvetelina Ivanova, Dora Levterova-Gadjalova, \\ Galin Tsokov, Nevena Mileva \\ University of Plovdiv "Paisii Hilendarski" Bulgaria
}

\begin{abstract}
The development of the world wide web and of Education 2.0. to Education 3.0. and Education 4.0. pose new challenges to the inclusive paradigm of higher education (HE) A study was conducted with the method of content analysis for the processes of inclusion in $\mathrm{HE}$ in the conditions of the new challenges. The applied research method is - quantitative content analysis of language categories - words and expressions that have a specific coding in the field of inclusive higher education and are located in the World wide web. Language categories are selected as census units according to the indicators time and frequency of occurrence in the world wide web. The quantitative content analysis method is applied with several groups of census units or conceptual schemes for inclusive higher education. The variations of the census units in the dynamics and correlation of the specified indicators manifest the interest shown in the problems of inclusive higher education by society, scientific analysis and scientific terms of the inclusive higher education, and the application of the Internet of Things, artificial intelligence for realization of the process of inclusive education. Specific emphasis is placed on the development of inclusive higher education from Education 2.0 to Education 4.0. The results demonstrate a change in HE to inclusive processes through personalized and self-determined training of students with different abilities and different potential in inclusive HE 3.0 and initial development of inclusive HE 4.0.
\end{abstract}

Keywords: Education 2.0, Education 3.0, Education 4.0, inclusive higher education, world wide web.

\section{Introduction}

According to the European Commission of Education: "Making higher education systems inclusive and connected to society requires providing the right conditions for students of different backgrounds to succeed. This goes beyond the question of offering financial support to disadvantaged groups, although this is vital for those from low-income backgrounds." The implemented policy poses challenges for inclusive education in higher 
educational institutions (HEIs). The current challenges include the implementation of inclusive processes in an digital environment.

The kaleidoscope of education, including inclusive education, changed as a result of the $4^{\text {th }}$ Industrial Revolution ( $4^{\text {th }}$ IR). As noted by Schwab (2016), Shahroom and Hussin (2018), the development of education is already "the stage in the development of knowledge in which the lines between physical, digital and biological spheres are being blurred" (p. 316).

The development of the world wide web in terms of distance learning in an digital environment inevitably affects the development of education. The development of the concepts of Education 2.0 to Education 3.0 and Education 4.0 brings new challenges to the inclusive paradigm of higher education. Conceptual schemes for the development of Education from 2.0 up to 4.0 are related to the application of technology in the educational process. According to Makrides and colleagues (2019), in Education 2.0 there is an invasion of technology in education; students have higher digital literacy and better internet browsing skills than some teachers; the virtual network provides a variety of digital resources that are used unsystematically. When Education 3.0 technologies are used everywhere in the educational process, learning is everywhere (anytime and anywhere), and students are self-learning. When Education 4.0 the technologies used in the educational process are innovative and easily accessible; there is personalized teaching and learning; flipped teaching is widely used; there is co-education (Schwab, 2016; Diwan, 2017; Makrides et al., 2019).

The development of Education 2.0 to Education 3.0 and to Education 4.0 follows the development of the world wide web from Web 2.0, through Web 3.0 and Web 4.0 to Web 5.0. Keser and Semerci (2019) note that Education 4.0, as a reflection of the era of Industry 4.0, refers to a period in which educational paradigms, approaches and technologies have changed. According to Halili (2019), "higher learning institutions are urge to revamp their education system and take initiatives to embrace the teaching and learning 4.0." (p. 63).

Changes in the educational process inevitably apply to inclusive processes in HEIs, especially during pandemic conditions or in situations of forced distance learning. Inclusive education in distance format in HEIs, during the COVID-19 pandemic:

- $\quad$ is already emerging from Web 2.0;

- is actively moving to Web 3.0;

- the transition to Web 4.0 is also underway;

- there is even a transition to Web 5.0;

- the development of Web 1.0. to Web 5.0., and future generations of the Web increase the knowledge and practices of and about inclusive education and inclusive society. 
Technology-based training allows ubiquitous learning with unlimited access to information. The information itself is provided in an accessible and equal way for students with different possibilities for its perception, with different potential for understanding it and with different perspectives for its use for both educational and life purposes. "The usage of technological advancements in education 4.0 is expected to present significant role for higher learning institution" (Blaschke, 2012).

For students with diversity needs in HEIs, the transition from one type of education to another type of education is as difficult as the transition from one activity to another activity in everyday life. It is extremely difficult to create a new routine and move from one routine to another.

Undoubtedly, the paradigm shift for inclusive education in HEIs provokes the scientific idea of finding solutions for the implementation of inclusive education at a distance in an digital environment. Solutions that are important for both teachers and students to implement effective and flexible learning, interactive communication and positive pedagogical interactions in terms of equal and fair presentation of e-learning resources and learning achievements.

The article provides content and narrative analysis of notions, concepts and types of scientific articles on inclusive higher education in order to present contemporary challenges. The focus is on four groups of problems that excite the researchers regarding the processes of inclusive education in higher education institutions in the development of the global network.

\section{Methodology}

The methodological reflection of the research is related to the establishment of the exploration of the dynamics of the processes of inclusive education in HEIs in the conditions of development of the world network. The method of quantitative content analysis is applied, in which the frequency presence of certain units in the text is interpreted. Its main feature is that it is considered and applied primarily as a technique for obtaining quantitative data about the direction, content, intention (latent or not) of the communication process, set in the analyzed texts (Ilcheva, 2006, p. 95).

\section{Objectivies:}

- definition of conceptual units for analysis;

- coding of predefined units of analysis;

- quantitative measurement of text arrays;

- empirical processing of the obtained data set;

- collecting data for phenomenography on the topic;

- quantitative and qualitative analysis of the obtained results. 


\section{The research Methodology includes:}

- method of content analysis for the processes of inclusion in higher education in the conditions of the new challenges;

- phenomenography or the influence of the global network for the development of inclusive higher education.

The criteria and the conceptual thesaurus of the conceptual schemes for research are divided into four groups. Coding of predefined units of analysis:

1. Group, which includes the following concepts, expressions and scientific articles with their analysis:

- inclusive education; inclusive education in HEIs; scientific articles for inclusive education in HEIs;

- inclusive attitudes, values and practices in HEIs; scientific articles for inclusive attitudes, values and practices in HEIs.

2. Group, which includes the following concepts, expressions and scientific articles with their analysis:

- inclusive attitudes in HEIs; scientific articles for inclusive attitudes in HEIs;

- inclusive values in HEIs; scientific articles for inclusive values in HEIs;

- inclusive practices in HEIs; scientific articles for inclusive practices in HEIs.

3. Group, which includes the following concepts, expressions and scientific articles with their analysis:

- inclusion in European Higher Education Institutions; scientific article for inclusion in European Higher Education Institutions;

- institutional responses for inclusive education; scientific article for institutional responses for inclusive education;

- equity and inclusion in European Higher Education Institutions; scientific article for equity and inclusion in European Higher Education Institutions;

- equity of inclusion in European Higher Education Institutions; scientific article for equity of inclusion in European Higher Education Institutions;

- personalised education in HEIs; scientific article for personalised education in HEIs;

- self-determination education in HEIs; scientific article for self-determination education in HEIs.

4. Group, which includes the following concepts, expressions and scientific articles with their analysis:

- inclusive education 2.0; scientific article for inclusive education 2.0.;

- inclusive education 3.0; scientific article for inclusive education 3.0; 
- inclusive education 4.0; scientific article for inclusive education 4.0;

- inclusive education in HEIs 2.0; scientific article for inclusive education in HEIs 2.0;

- inclusive education in HEIs 3.0; scientific article for inclusive education in HEIs 3.0;

- inclusive education in HEIs 4.0; scientific article for inclusive education in HEIs 4.0.

5. A group of codes with tracking defined terms and keywords include the 25 most common concepts and keywords in research, using the method of phenomenography through the prism of research attitudes.

\section{Period of study}

For groups of codes from 1 to 4 the survey was conducted three times: 22.01.2021-23.01.2021; 03.02.2021-04.02.2021; 26.05.2021-27.05.2021, and for group of codes/number 5 the survey was conducted twice: 04.02.2021 and 27.05.2021.

\section{Results}

The obtained results are followed through empirical processing of the obtained data set. The obtained results are presented in several tables. The tables are structured according to the coded words and expressions for analysis. The following algorithm is used for quantitative content analysis: selection of astronomical time for detection of the search of the pre-selected unit (term, expression, article title), within the selected time period, from half to one hour, for the individual groups registration is realized of the search in an interval of 3 minutes, the highest value of codified units of demand of all variations shall be selected and shall be marked as a value for the targeted time interval and time period.

Table 1. First group of codes

\begin{tabular}{|l|l|l|l|}
\hline Concept & $\begin{array}{l}\mathbf{2 2 . 0 1 . 2 0 2 1} \\
\mathbf{( 1 4 . 0 0 - 1 4 . 3 0 )}\end{array}$ & $\begin{array}{l}\mathbf{0 4 . 0 2 . 2 0 2 1} \\
\mathbf{( 1 4 . 0 0 - 1 4 . 3 0 )}\end{array}$ & $\begin{array}{l}\mathbf{2 7 . 0 5 . 2 0 2 1} \\
\mathbf{( 1 4 . 0 0 - 1 4 . 3 0 )}\end{array}$ \\
\hline $\begin{array}{l}\text { Inclusive } \\
\text { Education }\end{array}$ & $\begin{array}{l}462000000 \text { results } \\
(0.53 \text { seconds) }\end{array}$ & $\begin{array}{l}501000000 \text { results } \\
(0.49 \text { seconds })\end{array}$ & $\begin{array}{l}476000000 \text { results } \\
(0.58 \text { seconds })\end{array}$ \\
\hline $\begin{array}{l}\text { Inclusive } \\
\text { education } \\
\text { in HEIs }\end{array}$ & $\begin{array}{l}434000 \text { results } \\
(0.58 \text { seconds })\end{array}$ & $\begin{array}{l}474000 \text { results } \\
(0.52 \text { seconds })\end{array}$ & $\begin{array}{l}1040000 \text { results } \\
(0.64 \text { seconds })\end{array}$ \\
\hline $\begin{array}{l}\text { scientific } \\
\text { article } \\
\begin{array}{l}\text { Inclusive } \\
\text { education } \\
\text { in HEIs }\end{array}\end{array}$ & $\begin{array}{l}15800 \text { results } \\
(0.08 \text { seconds })\end{array}$ & $\begin{array}{l}15800 \text { results } \\
(0.08 \text { seconds })\end{array}$ & $\begin{array}{l}17900 \text { results } \\
(0.06 \text { seconds })\end{array}$ \\
\hline
\end{tabular}


The first group of codes is related to the issue of inclusive education in HEIs. As can be seen from the data obtained in Table 1, the publications in the world wide web are increasing.

While for the concept of "inclusive education" the increase of publications is smoother, for "Inclusive education in HEIs" the publications have an increase of $41.73 \%$ for a period of five months. Several explanatory models can be sought. While the issues of philosophy and concepts for inclusive education have been exploited for a much longer time, attention to inclusive education in HEIs has been focused in recent years. At the same time, in higher education there is a much larger palette of educational institutions (e. g. state, municipal, private, etc.), a very large fan of specialties and degrees (bachelor, master, $\mathrm{PhD}$ ), and many more digital, adaptive and assistive devices and technologies are used, many more digtal platforms, mobile applications, MOOCs, ORC and others are used by both university professors, administration and students. Research and research articles on inclusive education in HEIs are also steadily increasing.

The second group of codes is related to relations and inclusive practices in HEIs. Without inclusive relations to which attitudes and values refer, inclusive practices in HEIs cannot be realized. Table 2 clearly shows a renewed increase in publishing activity, both in terms of general paradigms and concepts of inclusive education in HEIs, and in the scientific reflection on inclusive education in HEIs. The time for searching for concepts for inclusive attitudes, values and inclusive practices is decreasing, which is an indicator of the increased interest in the issue.

Table 2. Second group of codes

\begin{tabular}{|l|l|l|l|}
\hline Concept & $\begin{array}{l}\mathbf{2 2 . 0 1 . 2 0 2 1} \\
\mathbf{( 1 5 . 0 0 - 1 6 . 0 0 )}\end{array}$ & $\begin{array}{l}\mathbf{0 4 . 0 2 . 2 0 2 1} \\
\mathbf{( 1 5 . 0 0 - 1 6 . 0 0 )}\end{array}$ & $\begin{array}{l}\mathbf{2 7 . 0 5 . 2 0 2 1} \\
\mathbf{( 1 5 . 0 0 - 1 6 . 0 0 )}\end{array}$ \\
\hline $\begin{array}{l}\text { inclusive attitudes } \\
\text { in HEIs }\end{array}$ & $\begin{array}{l}256000 \text { results } \\
(0.49 \text { seconds })\end{array}$ & $\begin{array}{l}275000 \text { results } \\
(0.47 \text { seconds })\end{array}$ & $\begin{array}{l}360000 \text { results } \\
(0.43 \text { seconds })\end{array}$ \\
\hline $\begin{array}{l}\text { scientific articles } \\
\text { inclusive attitudes } \\
\text { in HEIs }\end{array}$ & $\begin{array}{l}8200 \text { results } \\
(0.08 \text { seconds })\end{array}$ & $\begin{array}{l}9140 \text { results } \\
(0.09 \text { seconds })\end{array}$ & $\begin{array}{l}11500 \text { results } \\
(0.05 \text { seconds })\end{array}$ \\
\hline $\begin{array}{l}\text { inclusive values in } \\
\text { HEIs }\end{array}$ & $\begin{array}{l}434000 \text { results } \\
(0.58 \text { seconds })\end{array}$ & $\begin{array}{l}474000 \text { results } \\
(0.52 \text { seconds })\end{array}$ & $\begin{array}{l}546000 \text { results } \\
(0.53 \text { seconds })\end{array}$ \\
\hline $\begin{array}{l}\text { scientific articles } \\
\text { inclusive values in } \\
\text { HEIs }\end{array}$ & 0 & 0 & 1 result \\
\hline $\begin{array}{l}\text { inclusive practices } \\
\text { in HEIs }\end{array}$ & $\begin{array}{l}520000 \text { results } \\
(0.52 \text { seconds })\end{array}$ & $\begin{array}{l}524000 \text { results } \\
(0.52 \text { seconds })\end{array}$ & $\begin{array}{l}397000 \text { results } \\
(0.54 \text { seconds })\end{array}$ \\
\hline $\begin{array}{l}\text { scientific articles } \\
\text { inclusive practices } \\
\text { in HEIs }\end{array}$ & $\begin{array}{l}15000 \text { results } \\
(0.07 \text { seconds })\end{array}$ & $\begin{array}{l}15000 \text { results } \\
(0.07 \text { seconds })\end{array}$ & $\begin{array}{l}18800 \text { results } \\
(0.06 \text { seconds })\end{array}$ \\
\hline
\end{tabular}


Table 3 shows the results of the third group of codes related to the topic of inclusive education in European HEIs; the social responsibility of HEIs for the implementation of inclusive processes, which is synergistically related to the social capital of different students and different teachers; and the connection of inclusion with its quality. The latter emphasis is an important scientific and social trend, because the understanding of inclusion has many faces, but the actual inclusion is related to its quality, and accordingly could be measured by certain indicators.

Table 3. Third group of codes

\begin{tabular}{|l|l|l|l|}
\hline Concept & $\begin{array}{l}\mathbf{2 3 . 0 1 . 2 0 2 1} \\
\mathbf{( 1 6 . 0 0 - 1 7 . 0 0 )}\end{array}$ & $\begin{array}{l}\mathbf{0 5 . 0 2 . 2 0 2 1} \\
\mathbf{( 1 6 . 0 0 - 1 7 . 0 0 )}\end{array}$ & $\begin{array}{l}\mathbf{2 8 . 0 5 . 2 0 2 1} \\
\mathbf{( 1 6 . 0 0 - 1 7 . 0 0 )}\end{array}$ \\
\hline $\begin{array}{l}\text { Inclusion in } \\
\text { European Higher } \\
\text { Education } \\
\text { Institutions }\end{array}$ & $\begin{array}{l}278000000 \\
\text { results } \\
(0.60 \text { seconds })\end{array}$ & $\begin{array}{l}347000000 \\
\text { results } \\
(0.68 \text { seconds })\end{array}$ & $\begin{array}{l}364000000 p \\
\text { results } \\
(0.74 \text { seconds })\end{array}$ \\
\hline $\begin{array}{l}\text { scientific articles } \\
\text { Inclusion in } \\
\text { European Higher } \\
\text { Education } \\
\text { Institutions }\end{array}$ & $\begin{array}{l}1890000 \text { results } \\
(0.11 \text { seconds })\end{array}$ & $\begin{array}{l}1890000 \text { results } \\
(0.07 \text { seconds })\end{array}$ & $\begin{array}{l}2100000 \text { results } \\
(0.14 \text { seconds })\end{array}$ \\
\hline $\begin{array}{l}\text { Institutional } \\
\text { responses for } \\
\text { inclusive education }\end{array}$ & $\begin{array}{l}442000000 \\
\text { results } \\
(0.62 \text { seconds })\end{array}$ & $\begin{array}{l}524000 \text { 000 } \\
\text { results } \\
(0.68 \text { seconds })\end{array}$ & $\begin{array}{l}479000000 \\
\text { results } \\
(0.59 \text { seconds })\end{array}$ \\
\hline $\begin{array}{l}\text { scientific articles } \\
\text { Institutional } \\
\text { responses for } \\
\text { inclusive education }\end{array}$ & $\begin{array}{l}996000 \text { results } \\
(0.14 \text { seconds })\end{array}$ & $\begin{array}{l}996000 \text { results } \\
(0.06 \text { seconds })\end{array}$ & $\begin{array}{l}1130000 \text { results } \\
(0.12 \text { seconds })\end{array}$ \\
\hline $\begin{array}{l}\text { Equity and Inclusion } \\
\text { in European } \\
\text { Higher Education } \\
\text { Institutions }\end{array}$ & $\begin{array}{l}52000 \text { 000 results } \\
(0.52 \text { seconds })\end{array}$ & $\begin{array}{l}55900 \text { 000 results } \\
(0.73 \text { seconds })\end{array}$ & $\begin{array}{l}66300000 \text { results } \\
(0.68 \text { seconds })\end{array}$ \\
\hline $\begin{array}{l}\text { scientific articles } \\
\text { Equity and Inclusion } \\
\text { in European } \\
\text { Higher Education } \\
\text { Institutions }\end{array}$ & $\begin{array}{l}15000 \text { results } \\
(0.07 \text { seconds })\end{array}$ & $\begin{array}{l}324000 \text { results } \\
(0.19 \text { seconds })\end{array}$ & $\begin{array}{l}68600 \text { results } \\
(0.09 \text { seconds })\end{array}$ \\
\hline
\end{tabular}

Table 4 shows codes related to concepts and conceptual designations, which are a socio-economic reflection on the development of the World Wide Web. Just as the development of the World Wide Web in Web 2. models is evolving in the direction of Web 5. and reflects the development of education from Education 2.0 to Education 5.0, so education in the inclusive education cluster itself is evolving from Inclusive Education 2.0 to Inclusive Education 5.0 Undoubtedly, Web 5, Education 5.0. and 
respectively Inclusive Education 5.0 are still in the initial phase and therefore are not commented on. Inclusive education from 2.0 to Inclusive education 5.0 develops in both secondary and higher education.

Table 4. Fourth group of codes

\begin{tabular}{|c|c|c|c|}
\hline Concept & \begin{tabular}{|l|}
23.01 .2021 \\
$(17.00-18.00)$ \\
\end{tabular} & \begin{tabular}{|l|}
05.02 .2021 \\
$(17.00-18.00)$ \\
\end{tabular} & \begin{tabular}{|l|}
28.05 .2021 \\
$(17.00-18.00)$ \\
\end{tabular} \\
\hline Inclusive education 2.0 & $\begin{array}{l}32700000 \\
\text { results } \\
(0.77 \text { seconds }) \\
\end{array}$ & $\begin{array}{l}37800000 \\
\text { results } \\
(0.71 \text { seconds }) \\
\end{array}$ & $\begin{array}{l}37100000 \\
\text { results } \\
(0.60 \text { seconds }) \\
\end{array}$ \\
\hline $\begin{array}{l}\text { scientific articles } \\
\text { Inclusive education } 2.0\end{array}$ & $\begin{array}{l}195000 \text { results } \\
(0.16 \text { seconds })\end{array}$ & $\begin{array}{l}195000 \text { results } \\
(0.11 \text { seconds })\end{array}$ & $\begin{array}{l}221000 \text { results } \\
(0.11 \text { seconds })\end{array}$ \\
\hline Inclusive education $\mathbf{3 . 0}$ & $\begin{array}{l}42400000 \\
\text { results } \\
(0.72 \text { seconds })\end{array}$ & $\begin{array}{l}43000000 \\
\text { results } \\
(0.58 \text { seconds })\end{array}$ & $\begin{array}{l}46800000 \\
\text { results } \\
(0.57 \text { seconds })\end{array}$ \\
\hline $\begin{array}{l}\text { scientific articles } \\
\text { Inclusive education } 3.0\end{array}$ & $\begin{array}{l}142000 \text { results } \\
(0.16 \text { seconds })\end{array}$ & $\begin{array}{l}142000 \text { results } \\
(0.09 \text { seconds })\end{array}$ & $\begin{array}{l}167000 \text { results } \\
(0.11 \text { seconds })\end{array}$ \\
\hline Inclusive education 4.0 & $\begin{array}{l}54900000 \\
\text { results } \\
\text { (0.77 seconds) }\end{array}$ & $\begin{array}{l}53500000 \\
\text { results } \\
(0.80 \text { seconds })\end{array}$ & $\begin{array}{l}70100000 \\
\text { results } \\
(0.58 \text { seconds) }\end{array}$ \\
\hline $\begin{array}{l}\text { scientific articles } \\
\text { Inclusive education in } \\
\text { HEIs } 4.0\end{array}$ & $\begin{array}{l}189000 \text { results } \\
(0.08 \text { seconds })\end{array}$ & $\begin{array}{l}190000 \text { results } \\
(0.06 \text { seconds })\end{array}$ & $\begin{array}{l}224000 \text { results } \\
\text { (0.09 seconds) }\end{array}$ \\
\hline $\begin{array}{l}\text { Inclusive education in } \\
\text { HEIs } 2.0\end{array}$ & $\begin{array}{l}68900 \text { results } \\
(0.59 \text { seconds })\end{array}$ & $\begin{array}{l}76400 \text { results } \\
(0.61 \text { seconds })\end{array}$ & $\begin{array}{l}91500 \text { results } \\
(0.60 \text { seconds })\end{array}$ \\
\hline $\begin{array}{l}\text { scientific articles } \\
\text { Inclusive education in } \\
\text { HEIs } 2.0\end{array}$ & $\begin{array}{l}1930 \text { results } \\
(0.08 \text { seconds })\end{array}$ & $\begin{array}{l}1930 \text { results } \\
(0.05 \text { seconds })\end{array}$ & $\begin{array}{l}2360 \text { results } \\
(0.06 \text { seconds })\end{array}$ \\
\hline $\begin{array}{l}\text { Inclusive education in } \\
\text { HEIs } 3.0\end{array}$ & $\begin{array}{l}43200 \text { results } \\
(0.54 \text { seconds) }\end{array}$ & $\begin{array}{l}50600 \text { results } \\
(0.51 \text { seconds) }\end{array}$ & $\begin{array}{l}66200 \text { results } \\
(0.55 \text { seconds) }\end{array}$ \\
\hline $\begin{array}{l}\text { scientific articles } \\
\text { Inclusive education in } \\
\text { HEIs } 3.0\end{array}$ & $\begin{array}{l}1330 \text { results } \\
(0.07 \text { seconds) }\end{array}$ & $\begin{array}{l}1330 \text { results } \\
\text { (0.04 seconds) }\end{array}$ & $\begin{array}{l}1530 \text { results } \\
\text { (0.08 seconds) }\end{array}$ \\
\hline $\begin{array}{l}\text { Inclusive education in } \\
\text { HEIs 4.0 }\end{array}$ & $\begin{array}{l}71900 \text { results } \\
\text { (0.59 seconds) }\end{array}$ & $\begin{array}{l}94200 \text { results } \\
\text { (0.46 seconds) }\end{array}$ & $\begin{array}{l}66700 \text { results } \\
\text { (0.67 seconds) }\end{array}$ \\
\hline $\begin{array}{l}\text { scientific articles } \\
\text { Inclusive education in } \\
\text { HEIs } 4.0\end{array}$ & $\begin{array}{l}1770 \text { results } \\
(0.08 \text { seconds })\end{array}$ & $\begin{array}{l}1770 \text { results } \\
\text { (0.04 seconds) }\end{array}$ & $\begin{array}{l}2090 \text { results } \\
(0.06 \text { seconds) }\end{array}$ \\
\hline
\end{tabular}

The development of inclusive education in HEIs also assembles the relevant innovative teaching methods, changes teaching styles and learning styles in the dynamics of inclusive education from 2.0 to inclusive education 4.0 in HEIs. 
These dynamics are reflected in Table 5.

Table 5. Innovative methods in inclusive education

\begin{tabular}{|l|l|l|}
\hline Concept & $\mathbf{0 4 . 0 2 . 2 0 2 1}$ & $\mathbf{2 7 . 0 5 . 2 0 2 1}$ \\
\hline $\begin{array}{l}\text { Innovative methods in inclusive } \\
\text { education in HEIs 2.0 }\end{array}$ & $\begin{array}{l}802000 \text { results } \\
(0.71 \text { seconds })\end{array}$ & $\begin{array}{l}971000 \text { results } \\
(0.65 \text { seconds })\end{array}$ \\
\hline $\begin{array}{l}\text { scientific articles for Innovative } \\
\text { methods in inclusive education in } \\
\text { HEIs 2.0 }\end{array}$ & $\begin{array}{l}18000 \text { results } \\
\text { (0.11 seconds) }\end{array}$ & $\begin{array}{l}17900 \text { results } \\
(0.12 \text { seconds })\end{array}$ \\
\hline $\begin{array}{l}\text { Innovative methods in inclusive } \\
\text { education in HEIs 3.0 }\end{array}$ & $\begin{array}{l}594000 \text { results } \\
(0.64 \text { seconds })\end{array}$ & $\begin{array}{l}597000 \text { results } \\
(0.59 \text { seconds })\end{array}$ \\
\hline $\begin{array}{l}\text { scientific articles for Innovative } \\
\text { methods in inclusive education in } \\
\text { HEIs 3.0 }\end{array}$ & $\begin{array}{l}20600 \text { results } \\
(0.12 \text { seconds })\end{array}$ & $\begin{array}{l}20100 \text { results } \\
0.13 \text { seconds })\end{array}$ \\
\hline $\begin{array}{l}\text { Innovative methods in inclusive } \\
\text { education in HEIs 4.0 }\end{array}$ & $\begin{array}{l}634000 \text { results } \\
(0.64 \text { seconds })\end{array}$ & $\begin{array}{l}636000 \text { results } \\
(0.69 \text { seconds })\end{array}$ \\
\hline $\begin{array}{l}\text { scientific articles for Innovative } \\
\text { methods in inclusive education in } \\
\text { HEIs 4.0 }\end{array}$ & $\begin{array}{l}20600 \text { results } \\
(0.10 \text { seconds })\end{array}$ & $\begin{array}{l}20700 \text { results } \\
(0.13 \text { seconds })\end{array}$ \\
\hline
\end{tabular}

Although most often phenomenography refers to the understanding of the learning content by students, as a research method it works well in the field of inclusive education in HEIs as an attitude to promising trends in the topic and as an organization of acquaintance with the topic, defined in the style of Marton, Hounsell and Entwistle (1984).

The data is shown in Table 6 .

Table 6. Phenomenography of the perspectives of Inclusive Education in HEIs

\begin{tabular}{|l|l|l|}
\hline & $\begin{array}{l}\mathbf{0 4 . 0 2 . 2 0 2 1} \\
(\mathbf{1 7 . 0 0 - 1 8 . 0 0})\end{array}$ & $\begin{array}{l}\mathbf{2 8 . 0 5 . 2 0 2 1} \\
\mathbf{( 1 7 . 0 0 - 1 8 . 0 0})\end{array}$ \\
\hline $\begin{array}{l}\text { IR 4.0 and Inclusive Education } \\
\text { in HEIs }\end{array}$ & $\begin{array}{l}140 \text { 000 results } \\
(0.65 \text { seconds })\end{array}$ & $\begin{array}{l}176000 \text { results } \\
(0.58 \text { seconds })\end{array}$ \\
\hline $\begin{array}{l}\text { scientific articles for IR 4.0 and } \\
\text { Inclusive Education in HEIs }\end{array}$ & $\begin{array}{l}18200 \text { results } \\
(0.16 \text { seconds })\end{array}$ & $\begin{array}{l}18300 \text { results } \\
(0.12 \text { seconds })\end{array}$ \\
\hline $\begin{array}{l}\text { Artificial Intelligence (AI) in } \\
\text { Inclusive education in HEIs }\end{array}$ & $\begin{array}{l}420000 \text { results } \\
(0.64 \text { seconds })\end{array}$ & $\begin{array}{l}591000 \text { results } \\
(0.63 \text { seconds })\end{array}$ \\
\hline $\begin{array}{l}\text { scientific articles for AI in } \\
\text { Inclusive education in HEIs }\end{array}$ & $\begin{array}{l}20600 \text { results } \\
(0.13 \text { seconds })\end{array}$ & $\begin{array}{l}20800 \text { results } \\
(0.14 \text { seconds })\end{array}$ \\
\hline $\begin{array}{l}\text { Internet of Things (IoT) in } \\
\text { inclusive education in HEIs }\end{array}$ & $\begin{array}{l}223000 \text { results } \\
(0.69 \text { seconds })\end{array}$ & $\begin{array}{l}439000 \text { results } \\
(0.65 \text { seconds })\end{array}$ \\
\hline $\begin{array}{l}\text { scientific articles for IoT in } \\
\text { inclusive education in HEIs }\end{array}$ & $\begin{array}{l}17500 \text { results } \\
(0.09 \text { seconds })\end{array}$ & $\begin{array}{l}17500 \text { results } \\
(0.09 \text { seconds })\end{array}$ \\
\hline
\end{tabular}




\begin{tabular}{|l|l|l|}
\hline & $\begin{array}{l}\mathbf{0 4 . 0 2 . 2 0 2 1} \\
(\mathbf{1 7 . 0 0 - 1 8 . 0 0 )}\end{array}$ & $\begin{array}{l}\mathbf{2 8 . 0 5 . 2 0 2 1} \\
\mathbf{( 1 7 . 0 0 - 1 8 . 0 0 )}\end{array}$ \\
\hline $\begin{array}{l}\text { Virtual Reality (VR) and } \\
\text { Augmented Reality (AR) in } \\
\text { inclusive education in HEIs }\end{array}$ & $\begin{array}{l}68900 \text { results } \\
(0.71 \text { seconds) }\end{array}$ & $\begin{array}{l}424000 \text { results } \\
(0.65 \text { seconds })\end{array}$ \\
\hline $\begin{array}{l}\text { scientific articles for VR and AR } \\
\text { in inclusive education in HEIs }\end{array}$ & $\begin{array}{l}16400 \text { results } \\
(0.11 \text { seconds })\end{array}$ & $\begin{array}{l}16800 \text { results } \\
(0.10 \text { seconds })\end{array}$ \\
\hline $\begin{array}{l}\text { Intelligent robots in inclusive } \\
\text { education in HEIs }\end{array}$ & $\begin{array}{l}556000 \text { results } \\
(0.83 \text { seconds })\end{array}$ & $\begin{array}{l}853000 \text { results } \\
(0.68 \text { seconds })\end{array}$ \\
\hline $\begin{array}{l}\text { scientific articles for Intelligent } \\
\text { robots in inclusive education } \\
\text { in HEIs }\end{array}$ & $\begin{array}{l}19800 \text { results } \\
(0.09 \text { seconds })\end{array}$ & $\begin{array}{l}19700 \text { results } \\
(0.09 \text { seconds })\end{array}$ \\
\hline
\end{tabular}

\section{Discussion}

The issue of inclusive education in HEIs is in the process of searching, forming, and solving in action or in a project. Scientific research, explanatory models and inclusive practices are increasing. Inclusive education in HEIs is subject to serious scientific analysis. It is noteworthy that inclusive attitudes and practices enjoy increasing social and scientific interest. The scientific interest in inclusive practices in HEIs is higher than the scientific interest in inclusive attitudes in HEIs. An interesting fact is that inclusive values are not interpreted in the virtual network, unlike inclusive attitudes and practices. Only one result of the European Commission for Education was found in the last study, while in the previous two studies the result was zero. Presumably, values are implemented in inclusive attitudes and inclusive practices. A possible explanatory model is also the possible synergy of inclusive attitudes with the culture of the emerging pragmatism of inclusive practices. Although the two components appear dichotomous, they are in symbiosis.

An interesting fact, but easy to explain is that scientists' interest in "Inclusive education in HEIs 4.0" is higher than in "Inclusive education in HEIs 3.0". It is evident that there are more 440 articles. Public and scientific interest in innovative methods in inclusive education in HEIs is increasing. There is no reference to sentimental and old-fashioned categories, but the search for effective solutions through the virtual network and through innovative methods of teaching and administration.

On the web there is a connection between industrial revolution (IR 4.0) and Inclusive Education in HEIs. A serious connection is made between "IR 4.0 and Inclusive Education in HEIs" with a clear scientific interest. Of the various aspects of IR 4.0 and "Inclusive education in HEIs" the strongest demonstrated interest is in an "Intelligent robots in inclusive education in HEIs" follows an "Artificial Intelligence (AI)" and "Internet of Things (IoT)". 
At the same time, it is noteworthy that the interests of scientists have a different sequence. Phenomenographic analysis demonstrates the highest degree of interest and trust in "Artificial Intelligence (AI) in Inclusive education in HEIs" then in an "Intelligent robots in inclusive education in HEIs" and "Internet of Things (IOT) in inclusive education in HEIs" and the lowest in a "Virtual Reality (VR) and Augmented Reality (AR) in inclusive education in HEIs". Obviously, inclusive education in HEIs focuses on promising and legitimate models that outline current challenges for inclusive education in HEIs, but also highlight markers for upcoming challenges in the field of technology-based problems and technology-based decisions and follow-up.

Inclusive education in higher education is possible to be inclusive education from a distance in an electronic environment. It is feasible, much more possible for higher education than for secondary education. Undoubtedly there are problems to solve, but there are also amazingly creative solutions.

According to the European Agency for Special Needs and Inclusive Education (2020): "Comprehensive policies that focus on equity and inclusion can improve the overall effectiveness of education systems and the individual outcomes of learners. Increasing the inclusion of the educational system can lead to success for all students."

Data from phenomenography or the influence of the global network for the development of inclusive higher education show that technology-based training can have a beneficial effect on the application of innovative teaching methods and on student achievement in inclusive higher education.

\section{Conclusions}

A study was conducted with the method of quantitative analysis for the processes of inclusion in higher education in the conditions of the new challenges. It is clear from the research and analysis that the challenges facing inclusive higher education follow the snowball pattern - the more you study, the more challenges you find. At the same time, this effect is positive because it reveals specific and situational problems and solutions to them.

Technically based decisions and follow-up actions increase the opportunities for quality implementation of the process of inclusive education in HEIs. Rather technical innovation and IR 4.0 or IR 5.0 will lead Inclusive Education in HEIs in a clear path than changing inclusive attitudes and inclusive values in the HEIs. It is important that inclusive education in HEIs goes beyond the realm of diffusion, which is characterized by problems, ambiguity, unsolvable challenges and doubts about success. The challenges of inclusive education in HEIs only pave the way for confidence and stability. 
The limits of this article can be deduced in the direction of the limited content analysis period.

The study of the issues of and inclusive education in HEIs is undergoing flexible dynamic changes and new challenges, but it definitely leads to the realization of inclusive education systems.

\section{Acknowledgements}

The authors would like to thank the colleagues from the project Diversasia 618615-EPP-1-2020-1-UK-EPPKA2-CBHE-JP, funded by the European Union's Erasmus + program to partially fund this work.

\section{References}

Blaschke, L. M. (2012). Heutagogy and lifelong learning: A review of heutagogical practice and self-determined learning. International Review of Research in Open and Distance Learning 13(1), 56-71.

European Agency for Special Needs and Inclusive Education (2020). https://www. european-agency.org/

European Commission of Education, Inclusive and connected higher education (2020). https://ec.europa.eu/education/policies/higher-education/inclusive-and-connectedhigher-education_en

Diwan, P. (2017). Is Education 4.0 an imperative for success of $4^{\text {th }}$ Industrial Revolution? Accessed from https://medium.com/@pdiwan/is-education-4-0-an-imperativefor-success-of-4th-industrial-revolution-50c31451e8a4

Halili, S. H. (2019). Technological advancements in Education 4.0. The Online Journal of Distance Education and e-Learning, Volume 7, Issue 1, www.tojdel.net.

Илчева, Ю. (2006). Контент-анализът и изграждането на интелектуални карти в обучението по физика. Годишник на Минно-Геоложкия университет “Св. Иван рилски” Том 49, Св. IV, Хуманитарни и стопански науки. [Ilcheva, J. (2006). Content-analysis and intellectual cards formation in physics education. Annual of the University of Mining and Geology "St. Ivan Rilski" Vol. 49, Part IV, Humanitarian sciences and Economics.]

Keser, H., \& Semerci, A. (2019). Technology trends, Education 4.0 and beyond. Contemporary Educational Researches Journal, 9 (3), 39-49. https://doi.org/10.18844/cerj. v9i3.4269

Marton, F., Hounsell, D. \& Entwistle, N. (1984). The Experience of Learning. Edinburgh: Scottish Academic Press.

Makrides, G. et al (2019). The Evolution of Education from Education 1.0 to Education 4.0: Is It an Evolution or a Revolution?

Schwab, K. (2016). The Fourth Industrial Revolution. New York: Crown Publishing Group.

Shahroom, A. A., \& Hussin, N. (2018). Industrial Revolution 4.0 and Education. International Journal of Academic Research in Business and Social Sciences, 8(9), 314-319. 